\title{
ANALYSIS OF THE STUDENT LEARNING PROCESS IN LMS MOODLE
}

\author{
Milan PASTYǨÍI* ${ }^{*}$, Ostravská univerzita v Ostravě \\ Ingrid NAGYOVA, Ostravská univerzita v Ostravě
}

Přijato: 15. 3. 2016 / Akceptováno: 5. 7. 2016

Typ článku: Výzkumný článek

DOI: $10.5507 /$ jtie.2016.020

Abstract: The article describes the results of the data analysis recorded through the log reports in Moodle courses, a course specifically for the Educational Technology. The analysis compares data recorded in 2012 and 2013, separately for a group of full-time students and combined study. The paper shows the possibility of monitoring the students' activities in an e-learning course, from the viewpoint of the number of activities with respect to time and place of the action. The results of analysis point out the work styles of students in e-learning environment, the impacts of which there may have changes made in education. The analysis can simultaneously provide tutor feedback on the suitability and usability of learning materials in the course.

Key words: Moodle, LMS, Educational Technology, learning process, student activity, activity logs.

\section{ANALÝZA STUDIJNÍHO POSTUPU STUDENTU゚ V LMS MOODLE}

Abstrakt: Př́spěvek popisuje výsledky analýzy dat zaznamenávaných prostřednictvím log protokolu v kurzech v LMS Moodle, a to konkrétně v kurzu Vzdělávaci technologie. Analýza srovnává data zaznamenaná v letech 2012 a 2013 zvláš́t pro skupinu studentì prezenčni a kombinované formy studia. Př́spěvek ukazuje možnosti monitoringu činností studentì v e-learningovém kurzu, a to jednak z hlediska počtu činností, ale také s ohledem na misto a čas dané činnosti. Výsledky analýzy poukazuji na vybrané způsoby práce studenti̊ $v$ e-learningovém prostředi, na dopady, které zde mohou mit změny provedené ve výuce. Analýza může současně poskytnout tutorovi zpětnou vazbu ohledně vhodnosti a využitelnosti studijnich materiálì v kurzu.

Klíčová slova: Moodle, LMS, Vzdělávací technologie, studijní postup, činnost studenta, log protokoly o činnosti.

*Autor pro korespondenci: d15476@student.osu.cz 


\section{1 Úvod}

Rozvoj počítačů a zejména dostupnost internetu umožnil nástup e-learningu ve druhé polovině dvacátého století. Jeho rozvoj byl velmi rychlý, a to především v oblasti vysokého školství (Zlámalová, 2008). Pod pojmem e-learning rozumíme vzdělávání pomocí nových multimediálních technologií a internetu, Cross (2004) dokonce mluví o e-learningu jako o, životě v e-světě“. E-learning je často podporovaný systémem pro řízení a organizaci výuky LMS (Learning Management System), který v jednotlivých e-learnigových kurzech nabízí studentům studijní opory, instrukce ke studiu a práci, autoevaluační testy, úkoly, plány studia či diskusní fóra (Watson, Watson, 2007). LMS má potenciál vytvářet prostředí virtuální tř́́dy, $v$ němž je umožněna komunikace studentů s učitelem, ale i studentů mezi sebou. Výuka s podporou LMS může probíhat čistě elektronickou formou na dálku, bez fyzické účasti studentů ve škole nebo může být prezenční výuka spojená s e-learningem, co umožní využívat výhod obou forem učení (Klement a kol., 2012). Vzdělávání v e-learningovém prostředí má svá specifika, je charakteristické vyšší mírou samostatnosti a individuálnosti (Bates, Poole, 2003).

Př́íspěvek se zabývá analýzou studijních postupů studentů v e-learningovém kurzu. Pro analýzu byla využita data z log protokolů zaznamenávaných v prostředí Moodle (Use Reports, 2015). Cílem př́spěvku je ukázat, že podrobnější analýzou log protokolů lze získat informace o studijních postupech a práci studentů v kurzu a o jejich chování v e-learningovém prostředí. Př́spěvek rovněž naznačuje, jaké informace mohou poskytnout podobné analýzy prováděné $\mathrm{v}$ elektronických výukových prostředích. Vzhledem $\mathrm{k}$ velké skupině studentů $\mathrm{v}$ analyzovaném kurzu lze předpokládat možnost zobecnit získané informace o chování a práci studentů v e-learnigovém prostředí.

Příspěvek analyzuje data $\mathrm{z}$ e-learningového kurzu Vzdělávací technologie, který je vyučován na Pedagogické fakultě Ostravské univerzity v Ostravě. Předmět je určen pro studenty učitelsky zaměřených oborů a představuje pro ně obvykle jedinou možnost, jak si osvojit základní kompetence $\mathrm{v}$ oblasti informační gramotnosti potřebné pro vykonávání učitelské praxe (Nagyová, 2015). Tematicky je kurz zaměřen na práci s multimédii, na zpracování obrazu, tvorbu animací, práci se zvukem apod. Dovednosti studenti využívají při tvorbě multimediálních prezentací a dalších interaktivních pomůcek do výuky.

Pro výuku předmětu byl vytvořen kurz v prostředí LMS Moodle. Kurz je určen pro studenty prezenční i kombinované formy studia. Obsahuje studijní materiály, animace a návody pro práci studentů na korespondenčních úkolech. Významné využití má kurz v administraci korespondenčních úkolů (jejich zadání, sběr, hodnocení, úpravy, doplňování, atd.) a při testování znalostí studentů. Student za vypracování sedmnácti korespondenčních úkolů, dvou dotazníků a čtyřech testů může získat maximálně 100 bodů. Pro udělení zápočtu je požadován zisk minimálně 80 bodů. V prezenční formě studia studenti navštěvují jednou týdně cvičení a na těchto cvičeních si za pomoci učitele zpracovávají korespondenční úkolu v kurzu. Účast studentů v prezenční výuce není $\mathrm{z}$ důvodů možných kolizí $\mathrm{v}$ rozvrhu povinná. V kombinované formě studia studenti přijdou na prezenční výuku jednou za semestr a absolvují pouze odpolední prezenční tutoriál. Část úkolu musí řešit samostatně doma. (Pasty̌rík, 2015). 


\section{Výzkumné metody a metodologie zpracování dat}

$\mathrm{K}$ analýze jsou použita data získaná $\mathrm{z}$ výuky kurzu Vzdělávací technologie realizované v LMS Moodle v akademickém roce 2012/2013 a 2013/2014. Sledování dvou navazujících let umožní nahlédnout na rozdíly v činnostech studentů po změně v organizaci výuky a po přidání instruktážních videonahrávek vysvětlujících postup práce na jednotlivých úkolech krok po kroku. Instruktážní videonahrávky se staly oblíbenou součástí kurzu a předpokládáme, že výrazně ovlivní činnost studentů v kurzu. Po předchozích zkušenostech a $\mathrm{v}$ reakci na výsledky evaluace kurzu byl v roce 2013 zvýšen apel na návštěvu prezenčních tutoriálů pro prezenční studenty změnou v práci lektorů, kteř́ se snažili studentům vše lépe vysvětlit, motivovat je k práci a více s nimi spolupracovat. Účast na cvičeních zůstala z organizačních důvodů nadále nepovinná.

Data jsou dále rozdělena na prezenční (PS) a kombinovanou (KS) formu studia. Počet studentů $\mathrm{v}$ těchto letech byl zjištěn $\mathrm{z} \log$ protokolů (viz tabulka 1). Vznikly tak 4 skupiny studenti̊, jejichž studijní postupy v kurzu bylo možné mezi sebou porovnávat. Skupiny jsou dále značeny následovně: prezenční studium PS2012 a PS2013, kombinované studium KS2012, KS2013.

\begin{tabular}{|c|c|c|}
\cline { 2 - 3 } \multicolumn{1}{c|}{} & $\mathbf{2 0 1 2}$ & $\mathbf{2 0 1 3}$ \\
\hline PS & 384 & 348 \\
\hline KS & 212 & 118 \\
\hline Celkem & 596 & 466 \\
\hline
\end{tabular}

Tab. č. 1: Počet studentů v letech 2012 a 2013

Pro analýzu bylo nutné data $\mathrm{v} \log$ protokolech upravit a vhodně kategorizovat. Pro předzpracování byly využity metody filtrace (výběr atributů, řešení chybějících údajů), transformace (kategorizace), odvozování a pro dolování konverze na numerická data (Šarmanová, 2012).

Pro výběr a zobrazení požadovaných dat $\mathrm{k}$ analýze se $\mathrm{v}$ tabulkovém kalkulátoru Excel používají nástroje Automatický filtr, Rozšiřený filtr, Seřadit a funkce. Pro úspěšné filtrování dat bylo třeba, aby byly splněné dvě základní podmínky. Data nesmí obsahovat prázdné řádky nebo sloupce a musí obsahovat $\mathrm{v}$ jednom sloupci hodnoty stejného typu (Číhař, 2011).

Po shromáždění všech log protokolů o činnosti studentů v kurzu a jejich předzpracování byly vymezeny tři okruhy, které mohou poskytnout náhled na práci a chování studentů v e-learningovém prostředí:

- $\log$ protokoly,

- protokoly známek z kurzu, tj. hodnocení korespondenčních úkolů,

- výsledky testů a dotazníků v kurzu.

Analýzy log protokolů mohou poskytnout informace o činnostech studentů $\mathrm{v}$ průběhu práce v e-learningovém kurzu. Činností studenta $\mathrm{v}$ tomto článku rozumíme kliknutí na jednotlivé činnosti v Moodlu - student si otevře dotazník, podívá se na výukový materiál nebo zadání úkolu, odevzdá úkol, vyplní test atd. (Voborník, 2014).

Dále jsou prezentovány výsledky analýz ve formě tabulek a grafů dle Gavory (2010). 
Předpoklady a hypotézy vyplývající ze zkušeností s výukou v kurzu Vzdělávací technologie s ohledem na uvedené změny provedené ve výuce a struktuře kurzu:

H1: Celkový počet činností ve skupině prezenčních i kombinovaných studentů v roce 2013 výrazně poklesne.

H2: Celkový počet činností provedených ve škole ve skupině prezenčních studentů vzroste.

H3: Práce studentů s ohledem na dny v týdnu i v rámci semestru odpovídá rozvrhu prezenčních tutoriálů a termínům odevzdání korespondenčních úkolů.

\section{3 Činnosti studentů v e-learningovém kurzu}

$\mathrm{Na}$ činnosti studentů v kurzu lze nahlížet $\mathrm{z}$ hlediska místa (IP adresy činnosti) a času. IP adresy činností studentů umožní sledovat práci studentů ve škole v rámci prezenčních tutoriálů a doma (Škola, Doma) - viz graf 1 . Se znalostí IP adres počítačů na počítačových učebnách můžeme určit, že daná činnost byla provedena ve škole. Připouštíme, že zde mohou vznikat drobné chyby, které vhledem p počtu činností zanedbáváme.

Současně tabulka 2 přináší hodnoty Studentova t-testu a naznačuje významné rozdíly mezi sledovanými skupinami na hladině významnosti $\alpha=0,01$ (šedě podbarvené buňky tabulky).

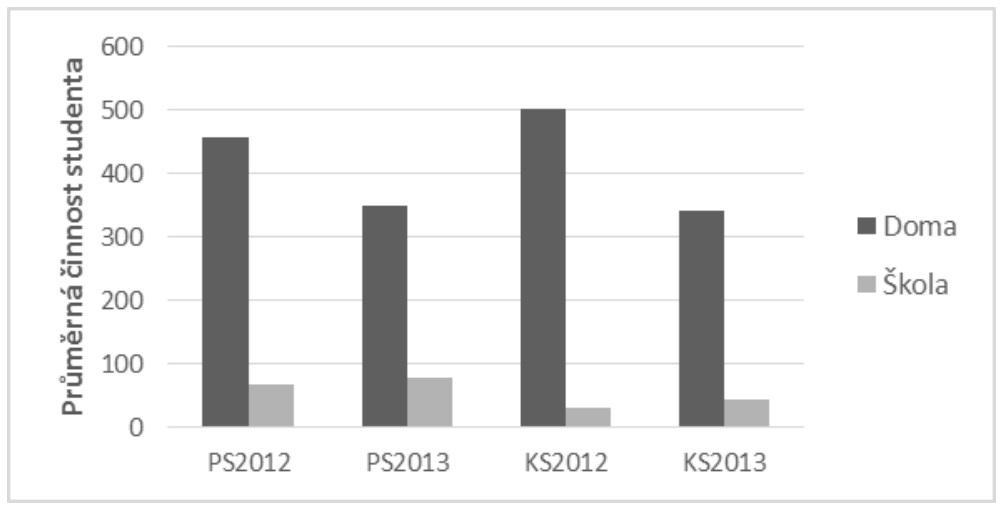

Graf č. 1: Činnost dle IP adresy

$\mathrm{V}$ roce 2013 došlo $\mathrm{k}$ významnému snížení činností studentů provedených $\mathrm{z}$ domácího prostředí, a to u studentů prezenční i kombinované formy studia. Současně došlo k mírnému nárůstu počtu činností ve škole, které ale není statisticky významné. $Z$ grafu lze vyčíst také výrazně nižší počet činností kombinovaných studentů (oproti studentům prezenčním) provedených ve škole, tabulka 2 potvrzuje statistickou významnost tohoto zjištění. Výsledek prímo souvisí s organizací studia kombinovaných studentů, kteří v porovnání s prezenčními studenty absolvují v průběhu semestru pouze jeden odpolední prezenční tutoriál. 


\begin{tabular}{|c|c|c|c|}
\hline & \multicolumn{2}{|c|}{ PS2012 } \\
\hline & & Doma & Škola \\
\hline \multirow{2}{*}{ KS2012 } & Doma & $-1,7312$ & \\
\hline & Škola & & 10,0103 \\
\hline \multirow{2}{*}{ PS2013 } & Doma & 6,48652 & \\
\hline & Škola & & $-2,4424$ \\
\hline
\end{tabular}

\begin{tabular}{|l|l|c|l|}
\cline { 3 - 4 } \multicolumn{2}{c|}{} & \multicolumn{2}{c|}{ KS2013 } \\
\cline { 3 - 5 } \multicolumn{2}{c|}{ PS2013 } & Doma & Škola \\
\cline { 3 - 4 } & Škola & 0,3850 & \\
\hline \multirow{2}{*}{ KS2012 } & Doma & 4,8804 & \\
\cline { 2 - 4 } & Škola & & $-4,7464$ \\
\hline
\end{tabular}

Tab. č. 2: Hodnoty Studentova t-testu, činnost dle IP adresy

Při testování nulové hypotézy nepředpokládající rozdíl $\mathrm{v}$ činnostech studentů mezi roky 2012 a 2013 jsme na hladině významnosti $\alpha=0,01$ vypočetli hodnotu testovacího kritéria pro prezenční studenty 5,93 a pro kombinované studenty 4,28 . $V$ obou př́padech jsou tyto hodnoty vyšší než kritická hodnota a proto nulovou hypotézu zamítáme. Pro studenty prezenční i kombinované formy studia existuje statisticky významný rozdíl $\mathrm{v}$ činnostech provedených $\mathrm{v}$ kurzu $\mathrm{v}$ letech 2012 a 2013, tj. před a po doplnění kurzu o instruktážní videa a změny v organizaci výuky kurzu pro prezenční studenty související $\mathrm{s}$ větším důrazem na pravidelnou a aktivní účast na cvičeních.

Činnosti studentů byly dále sledovány z hlediska času, a to po jednotlivých dnech $\mathrm{v}$ týdnu a podle času $\mathrm{v}$ průběhu dne.

Z pohledu jednotlivých dnů $\mathrm{v}$ týdnu bylo $\mathrm{v}$ roce 2012 prezenčními studenty provedeno nejvíce činností v neděli (viz graf 2). To jistě souvisí s termínem odevzdání úkolů, který je vždy nastaven na neděli. Prezenční tutoriály byly v roce 2012 rozvrhovány zejména $\mathrm{v}$ pondělí a pátek. $\mathrm{V}$ pondělí je průměrná činnost studentů $\mathrm{v}$ kurzu druhá nejvyšší, současně v pondělí bylo provedeno $26 \%$ aktivit ve škole. V pátek studenti do školy dochází méně, pouze $13 \%$ pátečních aktivit bylo provedeno ve škole.

V roce 2013 byly prezenční tutoriály rozvrhovány zejména ve čtvrtek a pátek. Ve čtvrtek bylo současně zaznamenáno nejvíce činností studentů v kurzu (viz graf 2), $\mathrm{z}$ nichž třetina $(33 \%)$ byla provedena ve škole. Počet činností v pátek provedených ve škole stoupl na dvojnásobek ( $26 \%$ činností bylo provedeno ve škole), i přesto, že jejich celkový počet se od roku 2012 nezměnil. Důraz a větší pozornost, věnovaná prezenčním tutoriálům, se projevila i $\mathrm{v}$ tom, že studenti výrazně méně pracovali v neděli a řešili úkoly až s termínem odevzdání. 


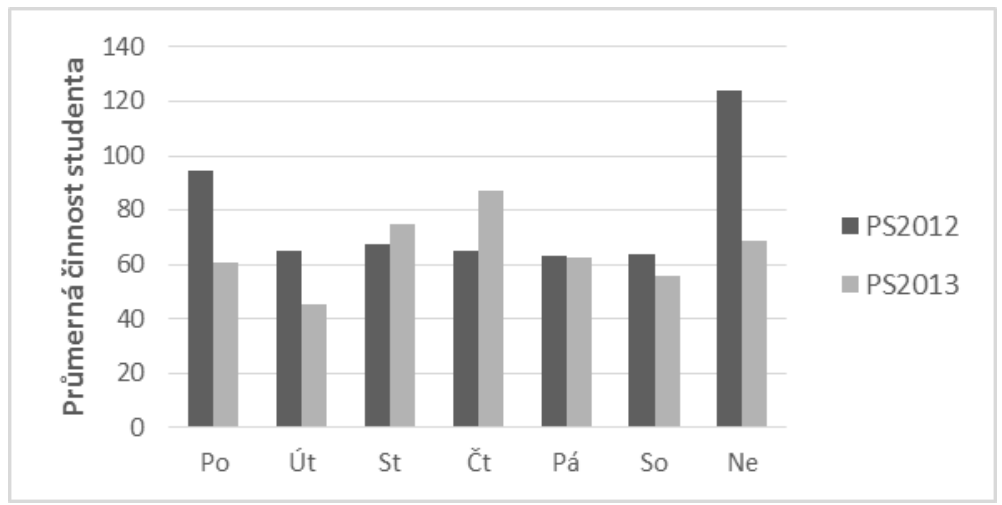

Graf č. 2: Činnost dle dnů v týdnu PS

Prezenční tutoriály kombinovaných studentů jsou rozvrhovány nejčastěji ve středu nebo v pátek. $V$ roce 2012 bylo v těchto dnech provedeno $8 \%$ činností studentů ve škole. $\mathrm{V}$ roce 2013 poměr činností ve škole $\mathrm{v}$ těchto dnech vzrostl na $16 \%$ činnosti ve středu a dokonce $30 \%$ v pátek. Rozdíly $\mathrm{v}$ činnostech studentů kombinované formy v jednotlivých dnech v týdnu se v letech 2012 a 2013 výrazněji neliší (viz graf 3). Nejnižší počet činností studenti prováděli $\mathrm{v}$ sobotu, kdy většina $\mathrm{z}$ nás $\mathrm{i}$ podle sociologických průzkumů věnuje čas rodině a odpočinku (Pácl, 1971). Tendenci studentů kombinované formy studia vypracovávat úkoly v pracovních dnech (mimo víkend) sledujeme již několik let. Naopak nejvyšší počet mimoškolních činností bylo zaznamenáno v obou letech ve čtvrtek.

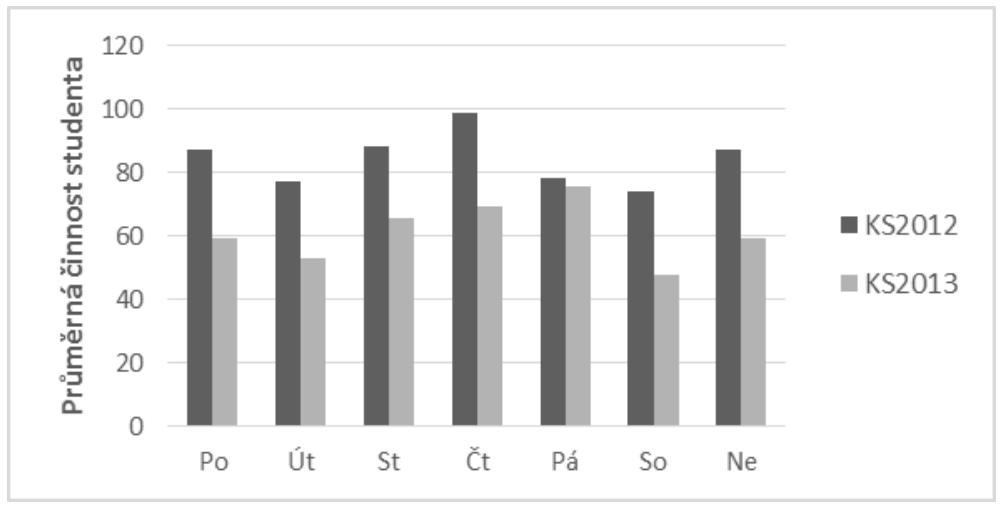

Graf č. 3: Činnost dle dnů v týdnu KS 
Ukazuje se, že počet činností studentů kombinované formy studia $\mathrm{v}$ jednotlivých dnech $\mathrm{v}$ týdnu je silně ovlivněn datem odevzdání korespondenčních úkolů, který je stanoven na 31. ledna daného akademického roku. Tabulka 3 uvádí podíl činností v posledních dnech před termínem odevzdání úkolu na celkovém počtu činností v daném dnu v týdnu. $V$ obou letech se závěrečné činnosti v kurzu kumulují na úterý až čtvrtek, kdy studenti provedou více než $25 \%$ aktivit v odpovídajících dnech v týdnu.

\begin{tabular}{|l|l|l|}
\hline 28.1 .2013 & Po & $25 \%$ \\
\hline 29.1 .2013 & Ut & $31 \%$ \\
\hline 30.1 .2013 & St & $25 \%$ \\
\hline 31.1.2013 & Čt & $28 \%$ \\
\hline 1.2 .2013 & Pá & $14 \%$ \\
\hline
\end{tabular}

\begin{tabular}{|l|l|l|}
\hline 27.1.2014 & Po & $15 \%$ \\
\hline 28.1.2014 & Ut & $28 \%$ \\
\hline 29.1 .2014 & St & $28 \%$ \\
\hline 30.1.2014 & Čt & $30 \%$ \\
\hline 31.1.2014 & Pá & $24 \%$ \\
\hline
\end{tabular}

Tab. č. 3: Podíl činností studentů KS před termínem odevzdání úkolů

Graf 4 názorně ukazuje rozdíly v činnosti studentů obou forem studia v roce 2013 v průběhu dne. Podobný graf pro rok 2012 včetně podílu činností provedených ve škole se odlišuje pouze $\mathrm{v}$ malých detailech, a proto ho zde neuvádíme.

Studenti PS vyvíjeli největší činnost mezi 10. a 12. hodinou dopoledne a pak v době kolem 21. hodiny večer. Podíl práce ve škole u studentů prezenční formy studia je nejvyšší ráno a v průběhu dopoledne (viz tabulka 4), kdy jsou rozvrhovány prezenční tutoriály. Ostatní činnosti studentů jsou prováděny mimo školu a jejich další interpretace je z log protokolu nejednoznačná.

Studenti KS vyvíjeli největši činnost v čase mezi 17. a 19. hodinou, tj. ve večerních hodinách po návratu $z$ práce. Přibližně čtvrtina činnosti mezi 14 . a 17 . hodinou je prováděna ve škole $\mathrm{v}$ čase prezenčních tutoriálů, které jsou rozvrhovány na odpoledne od 14:00 hodin (viz tabulka 4).

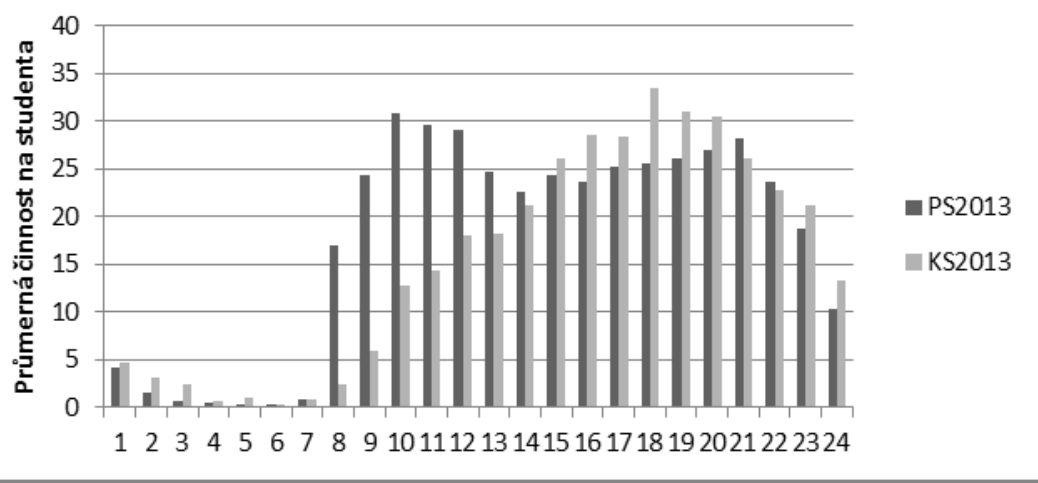

Graf č. 4: Činnost v průběhu dne PS a KS 2013 


\begin{tabular}{|l|c|}
\hline \multicolumn{2}{|c|}{ PS2013 } \\
\hline 7:00-7:59 & $84 \%$ \\
\hline 8:00-8:59 & $75 \%$ \\
\hline 9:00-9:59 & $61 \%$ \\
\hline 10:00-10:59 & $40 \%$ \\
\hline 11:00-11:59 & $25 \%$ \\
\hline 12:00-12:59 & $8 \%$ \\
\hline 13:00-13:59 & $1 \%$ \\
\hline
\end{tabular}

\begin{tabular}{|l|c|}
\hline \multicolumn{2}{|c|}{ KS2013 } \\
\hline 14:00-14:59 & $24 \%$ \\
\hline 15:00-15:59 & $25 \%$ \\
\hline 16:00-16:59 & $26 \%$ \\
\hline 17:00-17:59 & $18 \%$ \\
\hline 18:00-18:59 & $9 \%$ \\
\hline 19:00-19:59 & $3 \%$ \\
\hline 20:00-20:59 & $0 \%$ \\
\hline
\end{tabular}

Tab. č. 4: Podíl činnostív jednotlivých dnech v týdnu před termínem odevzdání úkolů

\section{Odevzdávání korespondenčních úkolů}

Srovnání mezi PS a KS v počtu odevzdaných úkolů v jednotlivých měsících poskytlo informaci o průběhu odevzdávání úkolů v rámci celého semestru. Graf 5 znázorňuje průměr odevzdaných úkolů na jednoho studenta $\mathrm{v}$ jednotlivých měsících zimního semestru v roce 2013. Opět neuvádíme graf pro rok 2012, protože celkový průběh, jak ho sledujeme rok od roku, se výrazně nemění.

Z grafu 5 lze vidět, že studenti PS mohou díky organizaci studia a pravidelným prezenčním tutoriálům řešit úkoly průběžně v semestru. Většina studentů má vše hotovo před koncem semestru (kalendářní týden 52 a 53). V roce 2012 bylo poslední den podle termínu odevzdání úkolů odevzdáno $28 \%$ úkolů, v roce 2013 tento počet výrazně poklesl, pouze $16 \%$ úkolů bylo odevzdáno na poslední chvíli.

Naopak studenti kombinované formy studia absolvují prezenční tutoriály v průběhu semestru (viz vyšší počet odevzdaných úkolů v 40., 47. a 50. týdnu). Úkoly, které v rámci prezenční výuky studenti nezvládli nebo úkoly určené pro domácí práci studenti řeší často až na poslední chvíli, těsně před termínem odevzdání úkolů (viz činnosti ve 2 . až 4. týdnu a pak zejména činnosti v pátém týdnu) - $23 \%$ úkolů bylo v roce 2013 odevzdáno až v posledním týdnu těsně před termínem odevzdání.

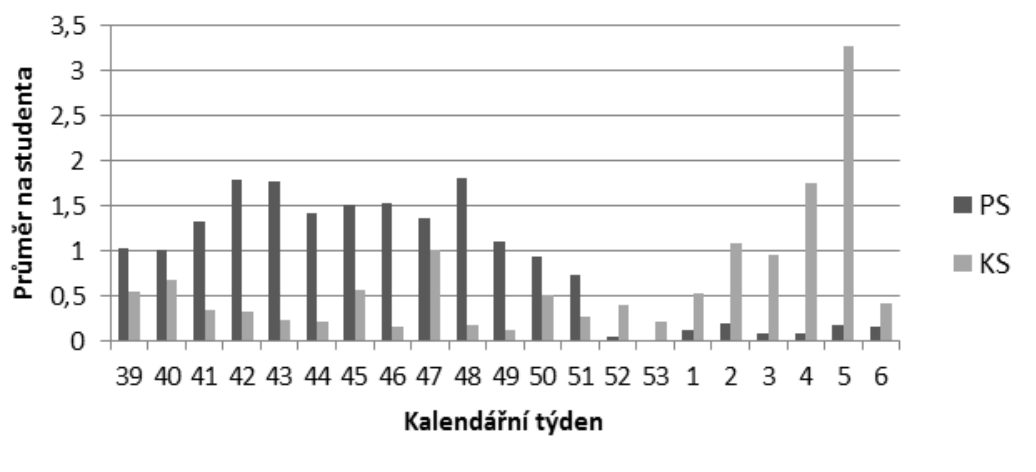

Graf č. 5: Odevzdáni úkolì po kalendárnich týdnech 


\section{Diskuze}

V rámci analýzy studijních postupo̊ studentů byly analyzovány log protokoly předmětu Vzdělávací technologie pro prezenční a kombinovanou formu studia. Analýza byla provedena ze záznamů z let 2012 a 2013. V přechodném období totiž došlo $\mathrm{k}$ výrazným změnám ve výuce zejména prezenčních studentů (důraz a motivace $\mathrm{k}$ vyšší návštěvnosti prezenční výuky) a ke změnám ve struktuře kurzu (instruktážní video tutoriály).

Uvedené změny měly př́mý dopad na práci a chování studentů. Záměrem analýzy bylo zjistit, zda lze tyto změny zaznamenat také prostředky, které e-learningová výuková prostředí nabízí. Zvolili jsme formu analýzy log protokolů.

Hypotéza H1 očekávající pokles počtu činností ve skupinách prezenčních i kombinovaných studentů se potvrdil - viz ověření pomocí Studentova t-testu uvedené v tabulce 2. Dá se předpokládat, že snížení počtu činností studentů v kurzu má prímou souvislost se snížením náročnost a nadbytečné zátěže kurzu. Tento předpoklad nelze samozřejmě z log protokolů zjistit.

Potěšitelné je, že pokud došlo k poklesu celkového počtu činností studentů, došlo u studentů prezenční i kombinované formy studia k nárůstu počtu činností provedených ve škole za odborné asistence a spolupráce s vyučujícím. Zaznamenaný nárůst není prozatím statisticky významný (viz hypotéza H2), očekáváme, že podíl domácí práce studentů bude postupně v dalších letech klesat.

Analýza potvrdila domněnky, které lze od vyučujících často slyšet - studenti si práci nechávají na poslední chvíli a úkoly řeší až s termínem odevzdání. Analýza prokázala, že přibližně pětina úkolů byla odevzdána na poslední chvíli. V tomto případě mají výhodu prezenční studenti, kteří mají termíny odevzdání úkolů rozvrženy rovnoměrně během semestru a práci $\mathrm{v}$ kurzu tak končí obvykle s koncem pravidelné výuky v semestru. Studenti kombinované formy studia jsou ovlivněni termínem 31. ledna a práci si nechávají na poslední chvíli. Strukturovanější rozvrhování termínů je pro kombinované studenty velice obtížné. Přesto by jistě stálo za úvahu alespoň zkušebně k tomuto kroku přistoupit. Problematické je také zatížení studentů KS o víkendech.

Předpoklad H3, který lze jen obtížně zformulovat do hypotézy, která by šla ověřit pouze analýzou log protokolů, je dokladován dílčími závěry. Jedná se jednak o získané informace o práci studentů na úkolech s ohledem na termín odevzdání úkolů. Dále jsme získali dílčí informace o práci studentů v kurzu v jednotlivých dnech v týdnu a také $\mathrm{v}$ průběhu dne.

\section{Závěr}

Článek popisuje možnosti analýzy studijních postupů studentů v e-learningovém prostředí při zpracování log protokolů a údajůn, které toto prostředí poskytuje. V rámci analýzy byla zpracovávána data z log protokolů kurzu Vzdělávací technologie, který je vytvořen a administrován v LMS Moodle. Data byla předzpracována a následně podrobena statistickému zpracování s využitím metod dolování dat.

Výsledky jednotlivých analýz byly prováděny pro kombinovanou a prezenční formou studia a pro dva akademické roky 2012/2013 a 2013/2014, kdy v přechodném období došlo ke změně výuky a také úpravám studijních materiálů (zejména doplnění instruktážních videí). $\mathrm{Z}$ dat se podařilo získat výstupy popisující studijní postupy 
a chování studentů z pohledu celkového počtu aktivit a podílu domácí př́pravy studentů, $\mathrm{z}$ pohledu činností studentů $\mathrm{v}$ průběhu dne, týdne či celého semestru. S podobnými analýzami se lze občas setkat na konferencích a seminárích (např́klad (Alves a kol., 2015)). Našim záměrem bylo ukázat maximální možnosti, které analýza log protokolů může nabídnout.

Naznačená analýza log protokolů má i problematické stránky. Omezení na technická data určují hranice toho, co lze analýzou získat. Analýzou log protokolů nezjistíme důvody, které studenty $\mathrm{k}$ danému chování vedou, neodhalíme to, co studenti skutečně mezi po sobě jdoucími činnosti doopravdy dělají, zda skutečně a zodpovědně studují nebo se věnují jiným záležitostem. I proto je zobecnění výsledků analýzy velice problematické. Navíc práce s velkým množstvím dat může i přes počítačové zpracování vést $\mathrm{k}$ chybám a $\mathrm{k}$ chybným závěrům, a to zejména při srovnávání výsledků za delší časové období, kdy se často mění i forma log protokolů v LMS.

Přesto lze konstatovat, že provedená analýza log protokolů může potvrdit nebo vyvrátit některé domněnky vyučujících v kurzu a poskytnout tak při pozorné interpretaci jistou zpětnou vazbu. Na jednotlivých krocích analýzy bylo možné sledovat dopady změn ve výuce, které se projevily v činnostech a chování studentů. S ohledem na množství dat by do budoucna užitečné informace mohla poskytnout hlubší analýza zaměřená na typy činností, na konkrétní studijní materiály a úkoly.

\section{Literatura}

Alves, P., Miranda, L. \& Morais, C. (2015). Record of Undergraduates' Activities in Virtual Learning Environments. ECEL 2015, Hatfield: ACPI, s. 25-33.

Bates, A., \& Poole, G. (2003). Effective Teaching with Technology in Higher Education. 1. ed., San Francisco: Jossey-Bass/John Wiley.

Cross, J. (2004). An informal history of eLearning. Horizon: Emerald Group Publishing Limited. [cit. 2016-05-5]. Dostupné z WWW: http://www.internettime.com/

Learning/articles/xAn\%20Informal\%20History\%20of\%20eLearning.pdf

Č́́hař, J. (2011). 1001 tipů a triků pro Microsoft Excel 2007-2010. Brno: Computer

Press.

Gavora, P. (ed.). (2010). Elektronická učebnica pedagogického výskumu. Bratislava: Univerzita Komenského. [cit. 2016-05-5]. Dostupné z WWW:

http://www.e-metodologia.fedu.uniba.sk/

Klement, M., M., Chráska, J., Dostál \& Marešová, K. (2012). E-learning: Elektronické studijni opory a jejich hodnocení. Olomouc: Gevak.

Konstantinidis, A. \& Grafton, C. (2013). Using Excel macros to analyse Moodle logs.

2nd Moodle Research Conference, Sousse, pp. 33-39.

Metodika pro hodnocení rozvoje informační gramotnosti. (2015). Praha: ČŠI. [cit. 201602-10]. Dostupné z WWW: http://www.niqes.cz/Metodika-gramotnosti/Metodika-prohodnoceni-rozvoje-informacni-gramotno

Nagyová, I. (2015). Analysis of Students' Behaviour in eLearning Course "Educational Technologies". European Conference on e-Learning Conference Proceedings: ACPI. s. 428-434.

Pastyř́ík, M. (2015). Analýza průchodu studentů kurzem Vzdělávací technologie 1. Diplomová práce. Ostrava: Ostravská univerzita. 
Pácl, P. (1971). Některé sociologické aspekty využití volných sobot. Brno: Sborník prací FFBU. Roč. 20, č. G15, s. 103-116

Quiz report statistics. Moodle. [cit. 2016-02-10]. Dostupné z WWW:

https://docs.moodle.org/dev/Quiz_report_statistics

Šarmanová, J. (2012). Metody analýzy dat: učebni text. Ostrava: VŠB-TU. [cit. 2016-02-

10]. Dostupné z WWW: http://www.person.vsb.cz/archivcd/FEI/MAD/MAD.pdf

Use Reports to Track Student Activity in Moodle. (2015). University of Massachusetts

Amherst: Information technology [online]. [cit. 2016-02-10]. Dostupné z WWW:

https://www.it.umass.edu/support/moodle/use-reports-track-student-activity-moodle Voborník, P. (2014). Základní moduly činností v Moodle. Hradec Králové: PřF HK. [cit. 2016-05-5]. Dostupné z WWW: http://download.petrvobornik.cz/docs/knihy/moodle.pdf Watson W. R., Watson S. L. (2007). An argument for clarity: what are learning management systems, what are they not, and what should they become? TechTrends. Springer Verlag, 51(2), s. 28-34.

Zlámalová, H. (2006). Distanční vzdělávání a eLearning: učebni text pro distanční studium. Praha: UJAK a NCDV Praha. 